\title{
Eşli Çalışan Düşey Eksenli Rüzgâr Türbinlerinin Yarı Karmaşık Bir Sahadaki Yıllık Enerji Üretiminin Değerlendirilmesi
}

\section{Estimation of Annual Energy Production of Coupled Vertical-Axis Wind Turbines in a Semi-Complex Terrain}

\author{
Ferhat Cem Başer 1 ${ }^{(0)}$, Ziya Haktan Karadeniz ${ }^{2 *}\left(\mathbb{0}\right.$, İskender Kökey ${ }^{3}{ }^{(0)}$, Alpaslan \\ Turgut 4 (i) \\ 1 İzmir Kâtip Çelebi Üniversitesi, Fen Bilimleri Enstitüsü, Makine Mühendisliği ABD, İzmir, TÜRKIYE \\ 2 İzmir Kâtip Çelebi Üniversitesi, Mühendislik ve Mimarlık Fakültesi, Makine Mühendisliği Bölümü, İzmir, TÜRKIYE \\ ${ }^{3}$ Dokuz Eylül Üniversitesi, Fen Bilimleri Enstitüsü, Enerji ABD, İzmir, TÜRKIYE \\ ${ }^{4}$ Dokuz Eylül Üniversitesi, Mühendislik Fakültesi, Makine Mühendisliği Bölümü, İzmir, TÜRKIYY
}

Sorumlu Yazar / Corresponding Author*: zhaktan.karadeniz@ikcu.edu.tr

\author{
Geliș Tarihi / Received: 20.05.2019 Araștırma Makalesi/Research Article \\ Kabul Tarihi / Accepted: 25.07.2019 DOI:10.21205/deufmd.2020226420 \\ Atıf sekli/How to cite BAŞER, F.C., KARADENIZ, Z.H., KÖKEY, I., TURGUT, A. (2020). Eşli Çalışan Düşey Eksenli Rüzgâr Türbinlerinin Yarı \\ Karmașık Bir Sahadaki Ylllı Enerji Üretiminin Değerlendirilmesi. DEUFMD 22(64),199-208.
}

Öz

Bir alana rüzgâr türbinleri yerleştirmek için bir rüzgâr kaynağı değerlendirmesi (RKD) yapılması gerekmektedir. Bu değerlendirme, rüzgâr tarlasının yerleştirilmesi, boyutlandırılması ve tasarım detaylandırması için önemli girdiler sağlar. Sahanın doğru tespitine ek olarak, rüzgâr türbinlerini en verimli șekilde yerleștirmek de önemlidir. Bu konuda geliștirilen bir yazılıma gerekli veriler sağlandığında, yıllık enerji üretimi (YEÜ) hesaplamaları gerçekçi bir şekilde yapılabilmektedir. Fakat bu programlar yatay eksenli rüzgâr türbinleri (YERT) için tasarlanmıştır. Bu yazılım paketlerini kullanarak düşey eksenli rüzgâr türbinleri (DERT) üzerinde yapılmış bir çalışma bulunmamasına rağmen, sadece türbin güç eğrisi tanımlanarak YEÜ hesaplanması mümkündür. Eşli çalışan türbinlerde ise türbinlerin arkalarında bıraktıkları rüzgâr gölgeleri performansı etkilediğinden, türbinlerin toplam ylllık enerji üretimi rüzgâr geliş yönünün bir fonksiyonudur. Bu nedenle türbinlerin yıllık enerji üretimi yl boyunca rüzgâr geliş yönünün değişimi göz önünde bulundurularak hesaplanmalıdır. Bu çalışmada, öncelikle ayrık çalışan iki DERT'in saha performansı incelenmiştir. Ayrıca etkileşim halinde eşli çalışan DERT'lerin bir rüzgâr tarlasına yerleștirilmesi ve YEÜ hesaplanabilmesi için bir yöntem önerilmiștir. Bu yöntem kullanılarak yapılan analizlerde eșli çalışan türbinlerin, ayrık çalışanlara göre YEÜ bakımından \%2'den \%11'e kadar performans artışı gösterebileceği bulunmuştur.

Anahtar Kelimeler: WAsP, düşey eksenli rüzgâr türbini, eșli çalışan DERT, rüzgâr kaynak değerlendirmesi

\section{Abstract}

In order to site wind turbines in a field, it is necessary to do a wind resource assessment (WRA). This assessment provide important inputs for the placement, sizing and design detailing of the wind farm. In addition to the correct determination of the site, it is also critical to place the wind turbines in the 
most efficient way. When the necessary data are provided to a software developed for this subject, the annual energy production (AEP) calculations can be made realistically. However, these programs are designed for horizontal-axis wind turbines (HAWTs). Although there is no study conducted on vertical-axis wind turbines (VAWTs) using these software packages, it is possible to calculate the AEP by simply defining a turbine power curve. In the case of coupled turbines, wake effect created by the turbines affect the performance of the wind turbines, thus the total annual energy production of the turbines is a function of the wind direction. For this reason, annual energy production of the turbines should be calculated by taking into consideration the change of wind direction during the year. In this study, firstly, the field performance of two VAWTs, which are separated, were investigated. In addition, a method has been proposed in order to place the coupled VAWTs in a wind farm and calculate their AEP. It was found that the turbines operating in this method could show performance increase from $2 \%$ to $11 \%$ compared to separated ones.

Keywords: WAsP, vertical axis wind turbine, coupled VAWT, wind resource assessment

\section{Giriş}

Dünyanın gün geçtikçe artan enerji ihtiyacı ile tükenmeye başlayan yeraltı kaynakları ve atmosferdeki karbon emisyonunun artışı ile geri dönülemez bir yola giden küresel ısınma sorunu insanlığ sürdürülebilir enerji kaynaklarına yöneltmeye başlamıştır. Bu sürdürülebilir enerji kaynaklarında rüzgâr enerjisi, teknolojinin ilerlemesiyle daha da güvenilir ve gelecek vaadeden hale gelmektedir. Rüzgârdaki mevcut enerji, rüzgâr hızının küpü ile orantılıdır ve bu sayede rüzgâr hızındaki küçük artmalar enerji üretiminde yüksek artışlar sağlamaktadır. Rüzgâr enerjisinin yenilenemeyen enerji kaynakları karșısında birçok sayıda yararı bulunmaktadır. Hava, su kirliliği ve çevreye zararlı atıklar olușturmaz ayrıca doğada bulunan fosil yakıtlar gibi yeraltı kaynaklarını tüketmez. Bu yönleriyle, rüzgâr enerjisinin, yakın gelecekte enerji üretiminde tüm dünyada büyük bir paya sahip olacağı öngörülmektedir.

Çoğu rüzgâr türbini tarlası devasa yatay eksenli rüzgâr türbinlerinden (YERT) oluşmaktadır. Bunun nedeni ise yüksek mekanik güç katsayılarına sahip olmalarıdır. Fakat YERT'ler birbirlerine yakın konumlara yerleștirildiklerinde, olușturdukları art izi (wake), birbirlerinin güç katsayılarına olumsuz etki etmektedir. Bu nedenle mevcut arazi kaynağı sınırlanmaktadır.

Tek bașına çalıșan bir düșey eksenli rüzgâr türbininin (DERT) güç katsayısı bir YERT'e göre çok daha düșüktür. Günümüz dünyasının yüksek enerji ihtiyaçları göz önünde bulundurulduğunda, yüksek verimle büyük miktarlarda elektrik üretimi öncelikli olduğundan DERT’ler hakkında yapılan çalışma sayısı YERT'lerle ilgili çalışma sayısına kıyasla çok azdır. Yapılan son araștırmalarda, iddia edildiği gibi taban alanı bașına enerji yoğunluğu kavramı ile eşli ve gruplar halinde çalışan DERT verimlerinin artması olguları birleştirildiğinde rüzgâr enerjisinden elektrik üretimi yaklaşımlarında bir değişim yaşanması söz konusudur. Eşli çalışan düşey eksenli rüzgâr türbini dizilimleriyle rüzgâr tarlalarının güç yoğunluğunun artmasını konu alan öncü bir çalışmada [1], bu türbin dizilimlerinin günümüz YERT sahalarına göre 6-9 kat daha iyi performans gösterdiği gerçek rüzgâr koșulları altında deneysel olarak ortaya konmuștur (Şekil 1). Birbirine yakın yerleștirilmiș rüzgâr türbinlerinden biri tarafından yakalanamayan enerjinin yakınındaki diğer türbin tarafından yakalanması nedeniyle santral sahası daha verimli kullanılabilmektedir [2].

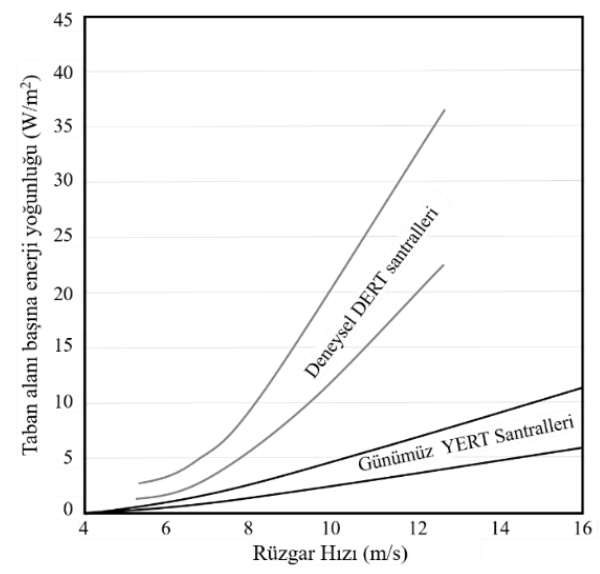

Şekil 1. Taban alanı bașına enerji yoğunluğunun ortalama serbest rüzgâr hızına bağlı değișimi [2] 
Literatürde, eșli çalıșan DERT'leri konu alan ilk ciddi bilimsel çalışma 2010 yılında yayınlanmıştır [3]. Taban alanı başına enerji yoğunluğu üzerinden yapılan karşılaștırmada, YERT santrallerine kıyasla önemli ölçüde artış sağlandığı açıklanmıștır. Ardından 2011 yılında Dabiri tarafından yapılan çalıșmada [1], eșli çalışan ve eşlerin birbirlerine zit yönde döndükleri Darrieus tipi DERT'ler kullanılarak kurulan deneysel santralde, gerçek rüzgar koşulları altında ölçümler yapılmıştır. Birçok farklı dizilimin denendiği bu çalışmada, önerilen santral ile günümüz YERT santrallerine göre, taban alanı başına enerji yoğunluğunun önemli ölçüde artırılabildiği görülmüştür. Kinzel ve ark., [4], 9 adet zit yönlerde dönen DERT çifti kullanan bir santral sahasındaki türbinler arasındaki enerji etkileşimini araştırmışlardır. Türbin art alanındaki rüzgar hızının serbest rüzgar hızının \%95'i seviyesine ulaşabilmesi için gereken mesafenin 6 türbin çapı olduğu belirtilmiştir. $\mathrm{Bu}$ değer, modern YERT'ler için gereken mesafenin yarısı kadardır. Ancak, yapılan noktasal ve eş zamanlı olmayan ölçümler, ayrıntılı analizler yapılabilmesi için gerekli çözünürlükte ve yeterlilikte değildir. Bu nedenle türbinler arası enerji aktarım mekanizmalarının belirlenmesinden çok genel bir değerlendirme yapılabilmiştir.

Literatürdeki güncel durumdan anlaşıldığı gibi DERT'ler hakkında yapılan çalıșmaların sayısı hızla artmaktadır. Yeni teknoloji ürünü deneysel ve sayısal yöntemlerin kullanımı ile farklı türbinlerin tekil kullanımdaki başarımları [5-7] ve birbirleriyle etkileşim halindeyken bașarımları güncel çalıșma alanlarıdır.

Rüzgâr türbini tarlalarının ve hatta tek bir rüzgâr türbininin bile kurulması için, öncelikle kurulacak arazinin karakteristiklerinin, rüzgâr yön ve hızlarının bilinmesi gerekmektedir. "Ne kadar enerji?" veya "ne kadar kapasite?" sorularını cevaplayabilmek için yapılacak olan rüzgâr kaynak değerlendirmesi (RKD) (wind resource assessment) büyük önem taşımaktadır. Rüzgâr kaynak değerlendirmesi, bir veya birkaç alan üzerinde rüzgâr kaynağı veya rüzgâr güç potansiyelini yaklaşı olarak hesaplama ișlemidir. $\mathrm{Bu}$ değerlendirme çeșitli bilgisayar yazılımları ile düșük hata oranlarıyla yaklaşık olarak yapılabilmektedir. Sahanın doğru belirlenmesinin yanında rüzgâr türbinlerini sahaya en verimli șekilde yerleștirilmesi de kritik öneme sahiptir. Böylece sahadaki potansiyelin, kullanılan türbinlerle ne kadarının elektrik enerjisine çevrilebileceği belirlenebilmektedir. Bu konu için geliştirilmiş yazılımlara (WAsP, WindPRO, WindSim vb.) gerekli veriler sağlandığında hesaplamalar gerçekçi şekilde yapılabilmektedirler. Büyük bir oranla sadece YERT'ler için tasarlanmış bu yazılımlarla düşey eksenli rüzgâr türbinlerine (DERT) yönelik çalışma yapmak ancak bazı değişikliklerle mümkün olabilmektedir. Literatürde bu konuyu ele alan bir çalışma bulunmamaktdır.

Bu çalışma YERT’ler için kullanılan yazılımlarda, birbiriyle etkileşim halinde çalıșan bir çift DERT'in ylllık enerji üretiminin belirlenmesi için bir yöntem önermektedir. Önerilen yöntem, literatürde daha önceden denenmemiștir ve çalışma sonucunun eşli çalışan DERT'lere yönelik analizlerin yaygınlaşmasına öncülük edeceği öngörülmektedir.

\section{Materyal ve Metot}

\subsection{Uygulama sahasının karakteristikleri}

Kullanılan saha İzmir'in kuzeyinde, Aliağa ilçesinde bulunmaktadır. Saha kuzey yönünden denize tamamen açık, küçük tepelere ve kısa bitki örtüsüne sahiptir (Şekil 2). Çok eğimli olmamakla birlikte neredeyse \%0'lık engebelilik (ruggedness) indeksine sahiptir. $70 \mathrm{~m}$ rakımda bulunan saha, kuzey doğu tarafından gelen hakim rüzgâr yönüne sahiptir (Şekil 3).

Türbinlerin konumlandırıldığı sahanın az eğimli ve küçük tepelere sahip olması ayrıca kıyı şeridinde bulunması sahayı yarı karmaşık olarak tanımlanan sınıfa sokmaktadır (Şekil 2).

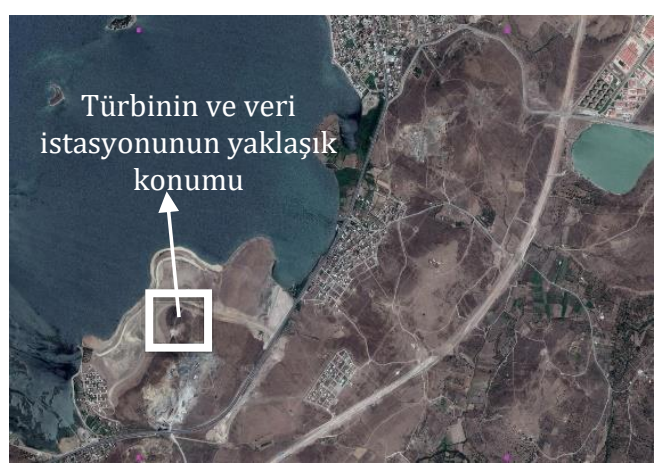

Şekil 2. Sahanın kuş bakıșı görüntüsü (38.862526 Enlemi, 27.047738 Boylamı)

Sahanın rüzgâr karakteristiklerini belirlemek için, 26 Haziran 2012 ve 1 Kasım 2013 tarihleri 
arasında kaydedilen yaklașık 15 aylık rüzgâr yön ve hız verileri, 10 dakikalık ortalamalarla, türbin konumu ile aynı noktada bulunan 60m'lik ölçüm direğinden alınmıștır. Direk üzerinden 30, 58 ve $60 \mathrm{~m}$ yüksekliklerden ölçüm yapılmıştır. Rüzgâr verileri ölçülürken, kullanılacak türbinin göbek yükseliğine (hub-height) en yakın yerden alınması gerekmektedir. Bu çalışma kapsamında eldeki veriler göz önünde bulundurulduğunda $10 \mathrm{~m}$ yüksekliğe en yakın yükseklik olan 30m'deki verilerin kullanılması sonuç açısından büyük farklara yol açmayacağı öngörülmüș ve kullanılacak yazılımın da bu değerleri belirli istatistiksel metodlar ile $10 \mathrm{~m}$ yüksekliğe taşıyabileceği bilindiğinden bu verilerin kullanılması uygun görülmüştür.

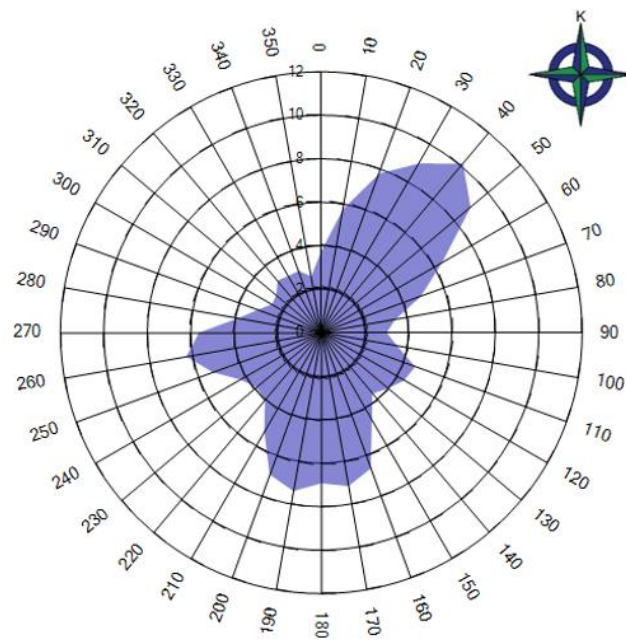

Şekil 3. Sahanın rüzgâr yön dağılımını gösteren rüzgâr frekans gülü

\subsection{Temel veriler}

Günümüzde, YEÜ hesaplamalarında kullanılan yazılımlar (örneğin WAsP ve WindPRO) YERT'lere yönelik tasarlanmıștır. Fakat belirli parametreler göz önüne alındığında DERT'lerin de bu yazılımlarla incelenebileceği görülmektedir. Bu çalıșmada kullanılan yazılım olan WAsP, art izi analizlerini YERT'lere özgün şekilde yapmaktadır. İtme katsayısı olarak adlandırılan parametre sayesinde art izi analizleri gerçeğe yakın şekilde yapılabilmektedir. Ancak, art izi analizi yalnızca birden fazla türbin sahaya konumlandırılacaksa önem taşımaktadır. Cünkü bu analiz sahadaki türbinlerin birbirleri ile olabilecek aerodinamik etkileşimlerini hesaplamada kullanılmaktadır. Bu çalışma sadece bir çift DERT için yapılmıştır.
Bunların birbiriyle etkileșimi bilindiğinden bu DERT çifti tek bir türbin gibi tanımlanabilmektedir. Böylece WAsP'ın türbin etkileșimi ile ilgili hesaplamaları sonucu etkilememektedir.

Eşli çalışan türbinlerde türbinlerin arkalarında bıraktıkları rüzgâr gölgeleri performansı etkilediğinden, türbinlerin YEÜ değeri rüzgâr geliş yönünün bir fonksiyonudur. $\mathrm{Bu}$ nedenle türbinlerin YEÜ değeri yıl boyunca rüzgâr geliş yönünün değişimi göz önünde bulundurularak hesaplanmalıdır. $\mathrm{Bu}$ hesaplamada kullanılabilecek literatürde önerilen veya ticari olarak satılan herhangi bir araç bulunmamaktadır. Ancak eşli çalışan DERT çiftinin toplam güç katsayısının (iki türbinin eşdeğer güç katsayısı) rüzgârın geliş yönüne göre değișimini inceleyen deneysel ve sayısal çalışmalar bulunmaktadır [1,3-8]. Böyle bir çalışmadan [1] alınan polar diyagram (Şekil 4), bu çalıșmada eșli çalıșan DERT performansı için ana veri kaynağı olarak kullanılmıştır. Seçilen veri $10^{\circ}$ çözünürlüğe sahiptir.

Çalıșmada kullanılan türbin șu anda ticari olarak piyasada da bulunan, $1,2 \mathrm{~m}$ rotor çapına ve $10 \mathrm{~m}$ yüksekliğe sahip Mariah Windspire 1,2-kW adlı türbinin modifiye edilmiş halidir. Bu türbinin karakteristik güç verileri (Şekil 5) NREL'in (Ulusal Yenilenebilir Enerji Laboratuarı) uluslararası standartlara (IEC 61400-12-1) uygun olarak yapilan saha testlerinin teknik raporundan [9] ve Dabiri [1] tarafından sunulan saha incelemesinden alınmıștır.

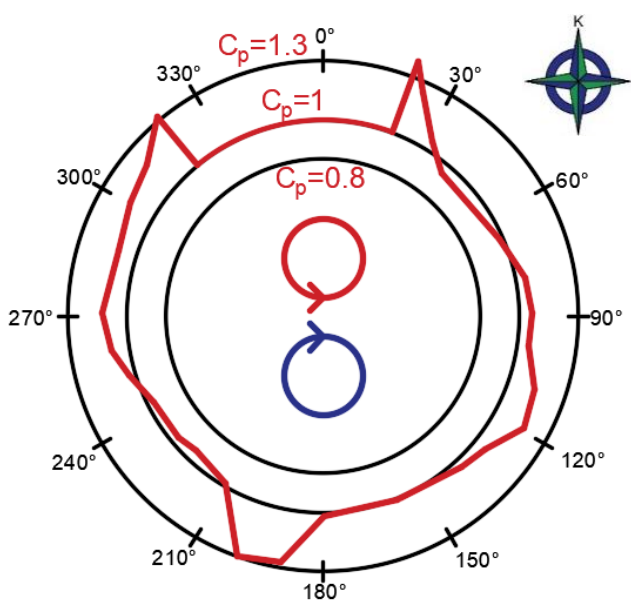

Şekil 4. Gelen rüzgâr yönüne karşı (açısal koordinat) normalize edilmiş güç katsayısının (radyal koordinat) değișimi (Kırmızı ve mavi daireler türbinleri göstermektedir.) [1] 


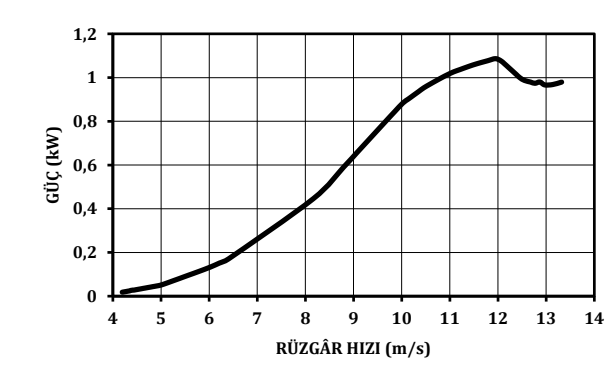

Şekil 5. Mariah Windspire 1.2-kW DERT güç eğrisi [9]

\subsection{Veri analizi}

Güç katsayısının rüzgâr yönüne bağlı olmadığı durumda, tek bir ortalama güç eğrisi ile hesaplamalar yapılabilir. Eşli çalışan türbinlerde türbinlerin güç katsayısı rüzgâr geliş yönünün de bir fonksiyonudur. Ancak kullanılan programda (WAsP) türbin güç eğrisinde böyle bir tanımlama mümkün değildir. $\mathrm{Bu}$ nedenle rüzgâr yönüne bağlı türbin güç katsayısı (Şekil 4) açısal koordinatlarda ayrıklaştırılmalıdır. $\mathrm{Bu}$ veri kullanılarak oluşturulan güç eğrileri ile her bir sektör için hesaplamalar yapılabilir.

Verilerin analizi yapılırken, türbinlerin, rüzgârın geliş yönüne bağlı davranışlarını inceleyebilmek için, Şekil 4'teki diyagram sektörlere ayrılır. Sektör sayısı n olmak üzere açısal aralıklar;

$$
\Delta \theta=\frac{360}{n}
$$

şeklinde belirlenir. Sektör sayısı ve açısal aralık değerleri belirlendikten sonra, sektörlerin türbinlerin çevresindeki konumlarının belirlenmesi gerekir. Şekil 6'da kuzey yönü referans alındığında, sektörlerin türbin çiftinin çevresindeki konumları gösterilmiștir.

Her bir $\Delta \theta_{\mathrm{i}}$ sektörü için ortalama $C_{\mathrm{p} \text {-normalize }}$

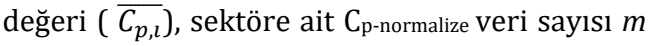
olmak üzere;

$$
\overline{C_{p, l}}=\frac{\sum_{j=1}^{m} C_{p-\text { normalize }, j}}{m}
$$

denklemiyle elde edilir ve tüm hesaplamalarda

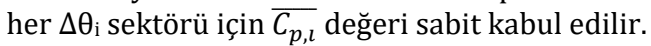

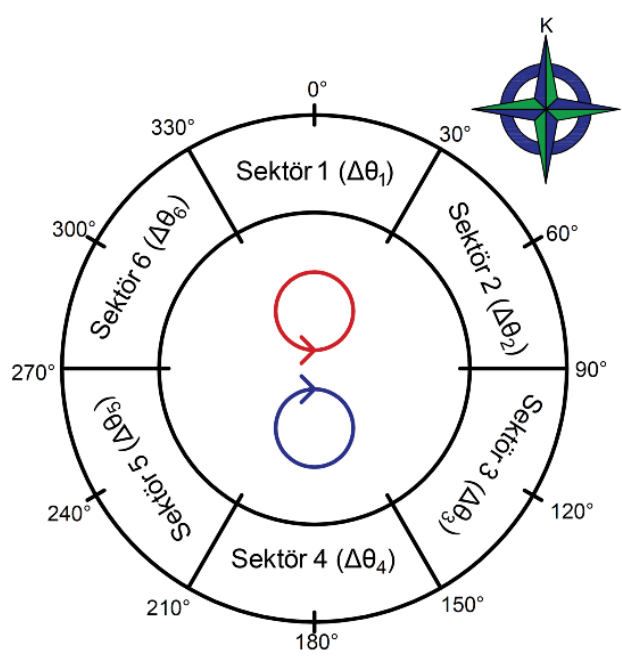

Şekil 6. Sektörlerin grafiksel gösterimi

Sektör sayısının (n) artırılmasıyla $\Delta \theta$ küçültülerek açısal çözünürlük artırılıp analizlerin doğruluğu artırılabilir. Bu çalışmada kaynak olarak kullanılan veri, $10^{\circ}$ açısal çözünürlüğe sahip olduğundan, $\Delta \theta^{\prime}$ nın değeri en küçük $10^{\circ}$ olabilir. Bundan büyük değerler için $\overline{C_{p, l}}$ değerini hesaplamak mümkündür. Şekil 7'de $\mathrm{n}=6$ durumu için $\overline{C_{p}}$ değerinin $\Delta \theta$ aralıklarıyla değişimi grafiksel olarak gösterilmiştir.

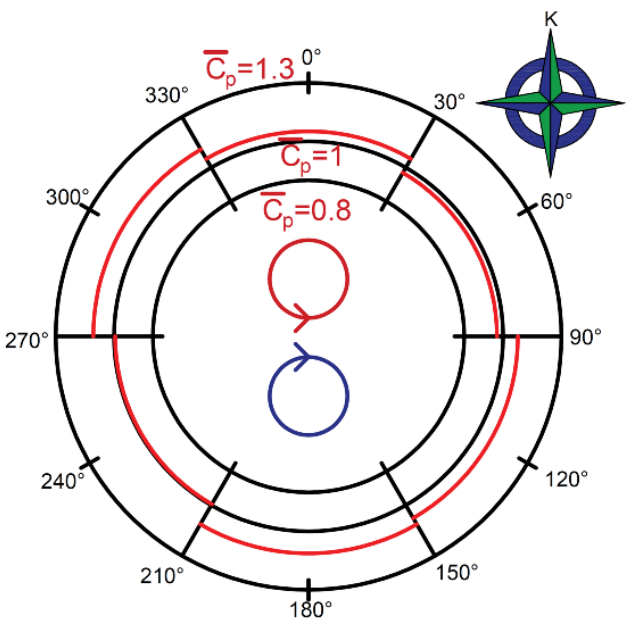

Şekil 7. Hesaplanan $\overline{C_{p, l}}$ değerlerinin örnek grafiksel gösterimi

Türbinlerin maksimum ve minimum performans sergiledikleri sektörler açısal aralıkların konumlarını belirlemek için kullanılabilir. Örneğin türbinlerin maksimum performans sergiledikleri bölge ile (örn; Şekil 7, $150^{\circ}-210^{\circ}$ ) 
sahanın maksimum potansiyelinin bulunduğu bölge (hakim rüzgâr yönü) (Şekil $3,15^{\circ}-75^{\circ}$ ) çakıștırılarak gerçekleştirilen bu konumlandırma esnasında, $\overline{C_{p, l}}$ değerleri diğer sektörlerde de yer değiştirmekte ve bunun sonucunda her bir türbin yerleşimi için türbin çiftine tüm yönlerden gelen rüzgârın etkisinin ayrı ayrı hesaplanması gerekmektedir. $\mathrm{Bu}$ nedenle hesaplanan $\overline{C_{p, l}}$ değerleri, tekil türbinin güç üretim değerleriyle çarpılarak, her açısal aralığa yeni bir türbin güç eğrisi tanımlanır.

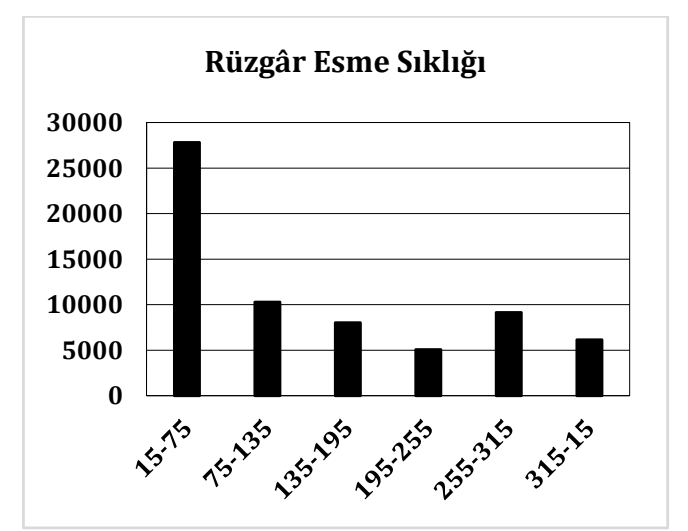

Şekil 8. Sektörlere göre rüzgâr esme sıklığı sayıları. $15^{\circ}-75^{\circ}$ ler arası hakim rüzgâr yönü olduğu gözükmektedir.

WAsP, YEÜ hesaplaması yaparken, sahadaki türbinleri YERT olarak kabul etmekte ve bu da her yönden gelen rüzgârın hesaba katılmasına neden olmaktadır. YERT'lerdeki dönme mekanizması (yaw) sayesinde bu durum gerçek koşullar altında da sağlanabilmektedir. $\mathrm{Bu}$ hesaplamayı eşli çalışan DERT çifti dizilimlerine uyarlamak için, her yönden gelen rüzgârın da sektörlere $\left(\Delta \beta_{\mathrm{i}}\right)$ ayrılması ve kendine ait olan $\Delta \theta_{\mathrm{i}}$ sektöründeki güç eğrisi ile analize sokulması gerekir. WAsP'ın her ayrı sektöre ait bulduğu YEÜ değeri, sadece o sektörde bulunan rüzgâr esme sıklığı sayısının $\left(\Delta \beta_{\mathrm{i}}\right)$ sahanın her yönden gelen toplam esme sıklığı sayısına $\left(\Delta \beta_{\text {toplam }}\right)$ oranıyla bulunan katsayı ile çarpılırak (Denklem 3) hesaplama yapılan sektöre ait gerçek YEÜ değeri bulunur.

$$
Y E \ddot{\mathrm{U}}_{W A s P, i} \times \frac{\Delta \beta_{i}}{\Delta \beta_{\text {toplam }}}=Y E \ddot{\mathrm{U}}_{\Delta \theta_{i}}
$$

Tüm sektörler için hesaplanan YEÜ değerleri toplanarak gerçek YEÜ bulunur.

$$
\sum_{i=1}^{n} Y E \ddot{\mathrm{U}}_{\Delta \theta_{i}}=Y E \ddot{\mathrm{U}}_{\text {Gerçek }}
$$

Uygulama sahası için yöne bağlı rüzgâr esme sıklığı sayıları Şekil 8'de, hesaplama yönteminin akış diyagramı Şekil 9'da verilmiştir.

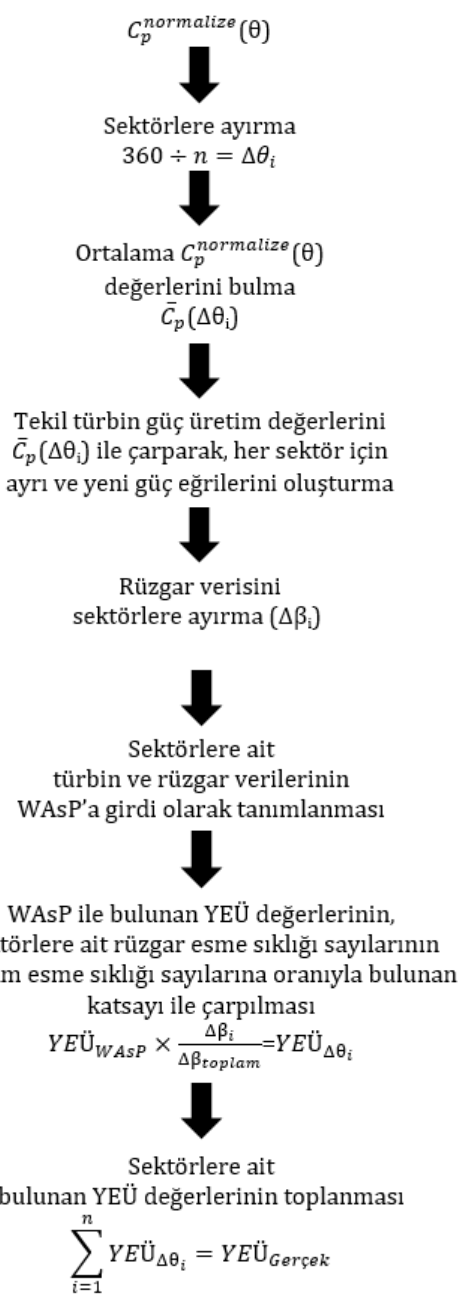

Şekil 9. Kullanılan yöntemin akış diyagramı

\section{Bulgular ve Tartışma}

\section{1. Örnek uygulama}

Önerilen yöntemin örnek türbin tipi kullanılarak sahaya uygulanması için Șekil 4'teki diyagramda, polar koordinatlarla belirtilen güç katsayısı 
çizgisi (kırmızı çizgi), türbinlerin farklı performans göstermesi beklenen sektörlerde, 6 adet $60^{\circ}$ lik açısal bölgeye ayrılmıştır. $\mathrm{Bu}$ bölgeler için hesaplanan $\overline{C_{p, l}}$ değerleri (Şekil 7) ile sahanın rüzgâr yön dağılımı verisi (Șekil 3) birleștirilerek türbin saha eşleşmesi Şekil 10'da görselleștirilmiștir. Șekil 10 'da verilen iki ayrı türbin yerleşimi durumu, YEÜ değerini en yüksek değere getirebilmek için, türbin çiftinin performansının yöne bağlı değișiminin saha verileri ile birleștirildiği bir optimizasyon çözümü yapılması gerektiğini göstermektedir.

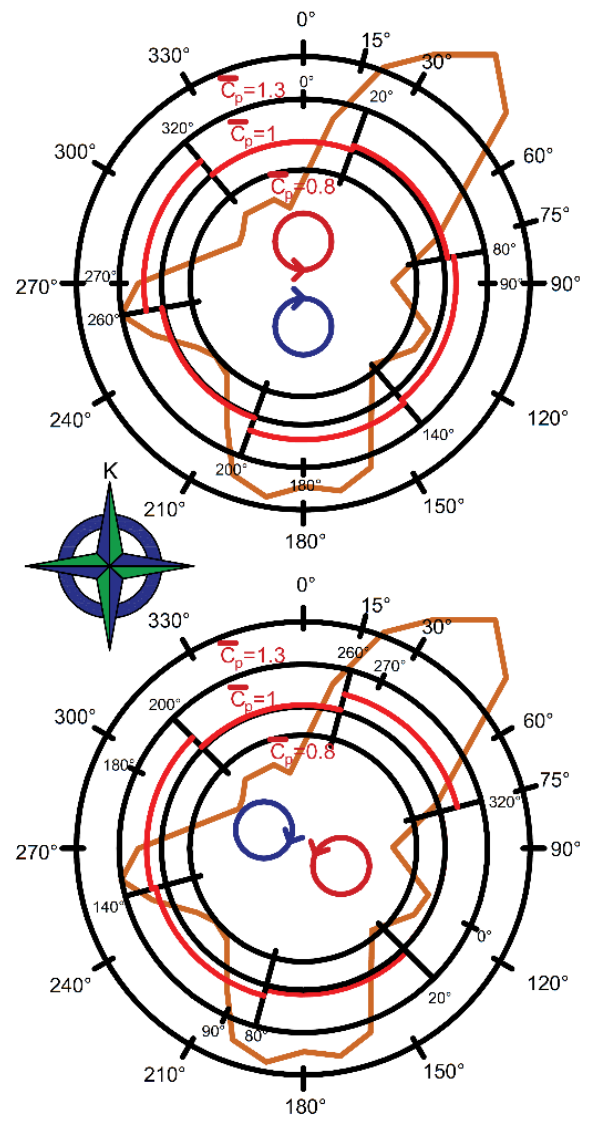

Şekil 10. Güç katsayısı çizgisi ve türbinlerin hakim rüzgâr yönünü karșıdan alacak șekilde dönüşü. Kırmızı çizgiler $\overline{C_{p, l}}$, kahverengi çizgi ise rüzgâr yön dağılımını göstermektedir.

Türbin çiftinin sahadaki performansın değişimini göstermek için örnek olarak, türbinlerin iyi veya kötü performans sergiledikleri 3 bölge seçilmiştir. Bunlar;
a. $\quad 30^{\circ}-90^{\circ}$ arası (kötü performans)
b. $\quad 150^{\circ}-210^{\circ}$ arası (iyi performans)
c. $260^{\circ}-320^{\circ}$ arası (çok iyi performans)

$\mathrm{Bu}$ bölgeler seçilirken, $270^{\circ}-330^{\circ}$ yerine $260^{\circ}$ $320^{\circ}$ diziliminin özel olarak seçilmesinin nedeni, bu açı aralığının en yüksek $\overline{C_{p}}$ değerine sahip olunan $60^{\circ}$ lik aralık olmasıdır.
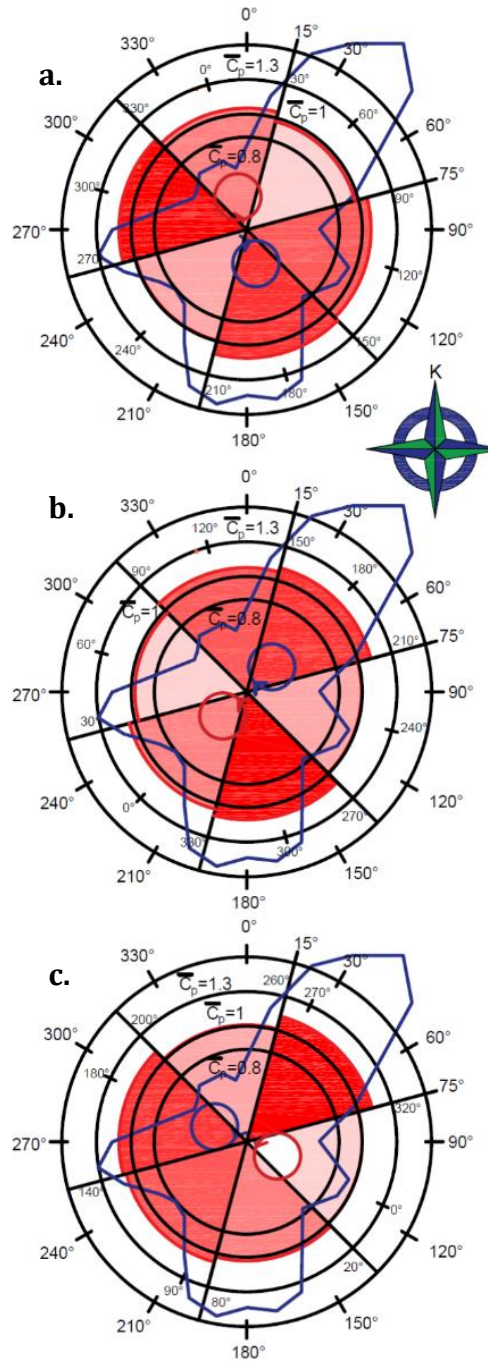

Şekil 11. Farklı açısal konumların sektörlere göre performansının șematik gösterimi. (Renk koyulaștıkça $C_{p}$ değeri artmaktadır.) (a: $30^{\circ}-90^{\circ}$ b: $150^{\circ}-210^{\circ}$, c: $260^{\circ}-320^{\circ}$ )

Türbin çiftinin sahaya yerleșiminde olușabilecek farklı olasılıkları değerlendirebilmek için, bu bölgelerin hakim rüzgâr yönünü $\left(15^{\circ}-75^{\circ}\right.$ arası) karşıdan alacak șekilde yerleştirildiği farklı 
durumlar için karșılaștırma yapılmıștır. hesaplama yapılan yerleșimler Șekil 11'de gösterilmiştir. Örnek olarak, en yüksek $\overline{C_{p, l}}$ değerine sahip sektör olan $260^{\circ}-320^{\circ}$ yerleșimi olușturulurken (Șekil 11-c), $260^{\circ}-320^{\circ}$ arası hakim rüzgâr yönünü karşıdan alacak şekilde yer değiștirirken kalan diğer $60^{\circ}$ lik bölgeler de birlikte yer değiștirmektedir. $\mathrm{Bu}$ farklı yerleşimlerin sonucu, saha üzerinde aynı konumda bulunan ve ayrık çalışan (birbirleriyle etkileșime girmeyecek kadar uzak yerleștirilmiş) iki adet DERT'in performansı ile karşılaștırılmıştır.

Farklı sektörlerde türbinlerin tepkisini ayırt edebilmek için açısal aralıklara karşılık gelen ortalama normalize güç katsayısı değerleri , izole türbinin güç üretim değerleri ile çarpılmıștır. Analizler yapılırken her $60^{\circ}$ lik açısal bölge için kullanılan türbin güç eğrileri Șekil 12'de gösterilmiştir. Şeklin ayrıntısında da görüldüğü gibi düşük rüzgâr hızlarında türbin güç eğrileri arasındaki fark sektörel güç katsayısı ile orantılı olarak değişmektedir.

Yapılan analizler sonucu ayrık çalıșan iki DERT'in toplam YEÜ $2990 \mathrm{kWs}$ bulunmuştur. Eşli çalıșan DERT çiftleri en kötü senaryoda $\left(30^{\circ}\right.$ $90^{\circ}$ ) bile $\% 2,25^{\prime}$ lik YEÜ artışı ile ayrık çalışan iki türbinden yüksek performans gösterebilmektedir. Eșli çalıșan tübinler en iyi durumda $\left(260^{\circ}-320^{\circ}\right) \% 11^{\prime} i$ aşan performans artışı göstermiștir (Tablo 1). Türbinin ürettiği ylllk ortalama gücün türbinin anma gücüne oranı olan kapasite kullanım faktörü [10] açısından değerlendirildiğinde türbinlerin sahadaki ticari performansı daha net olarak anlașlabilmektedir. Tablo 1'de farklı yerleșimler için kapasite kullanım faktörü de verilmiștir.

Tek bir çiftte görülen \%10'un üzerindeki artış hem teknik hem de ticari açıdan tatmin edici bir sonuçtur. Sektör sayısının (n) artırılmasıyla açısal aralık $(\Delta \theta)$ küçültülerek açısal çözünürlük artırılıp analizlerin doğruluğu artırılabilir.

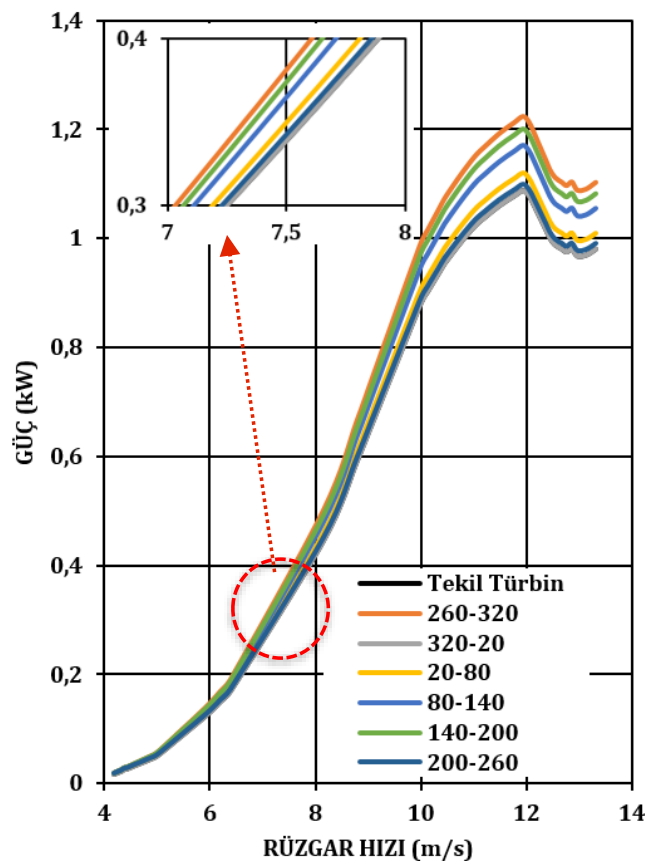

Şekil 12. $260^{\circ}-320^{\circ}$ diziliminin sektörlere göre güç eğrisi değișimleri $\left(320^{\circ}-20^{\circ}\right.$ arasını temsil eden güç eğrisi, tekil türbinin güç eğrisine eşit olduğundan siyah çizgi ve gri çizgi çakışmıştır.)

Tablo 1. Eşli çalışan DERT çifti dizilimlerinin YEÜ'lerinin, ayrık çalışan iki DERT’in toplam YEÜ’ne göre performans artışı

\begin{tabular}{llll}
\hline Dizilim & YEÜ $(\mathrm{kWs})$ & Performans Artışı & Kapasite Faktörü \\
\hline Ayrık Çalıșan & 2990 & - & $\% 28,4$ \\
$30^{\circ}-90^{\circ}$ & 3059 & $\% 2,25$ & $\% 29$ \\
$150^{\circ}-210^{\circ}$ & 3349 & $\% 10,73$ & $\% 31,8$ \\
$260^{\circ}-320^{\circ}$ & 3374 & $\% 11,37$ & $\% 32$
\end{tabular}




\subsection{Belirsizlik analizi}

Çalışmada kullanılan 30m'deki rüzgâr verileri 10m'ye ekstrapole edilirken WAsP 10'un rüzgâr iklim tahmin algoritması kullanılmıștır. $\mathrm{Bu}$ algoritma $5 \mathrm{~m}$ 'ye kadar tahmin yapabilmektedir fakat doğruluğu açısından kesin bir bilgi literatürde bulunmamaktadır. Ancak WAsP'a ait öğretici dökümanlarda, düşey hız profili ekstrapolasyonunun hata oranının \%0-5 arasında olduğu belirtilmektedir [11].

Rüzgâr verilerinin ekstrapolasyonunun doğruluğunu test etmek için, türbinin göbek yüksekliği $10 \mathrm{~m}$ 'den $30 \mathrm{~m}$ 'ye çıkarılarak analizler tekrar yürütülmüştür. Sonuç olarak, izole edilmiș tek bir türbin için YEÜ, 543 kWs artış ile, 1495 kWs'ten 2038 kWs'e çıktığı görülmüștür (Tablo 2). WAsP 10'un ekstrapolasyon algoritmasının $10 \mathrm{~m}$ yüksekliğin altında belirli düzeyde çalıștığı fark edilmiștir; ancak doğruluğunun daha ayrıntılı bir șekilde araștırılması gerekmektedir.

Tablo 2. Tekil türbinin farklı yüksekliklerdeki YEÜ değerleri

\begin{tabular}{ll}
\hline Yükseklik & YEÜ $(\mathrm{kWs})$ \\
\hline $10 \mathrm{~m}$ & 1495 \\
$30 \mathrm{~m}$ & 2038 \\
\hline
\end{tabular}

Hesaplamalar yapılırken, $70 \mathrm{~m}$ rakımda bulunan ve ortalama hava sicaklığ yll boyu $18^{\circ} \mathrm{C}$ olan sahanın hava yoğunluğu değeri yaklaşık 1,2 $\mathrm{kg} / \mathrm{m}^{3}$ alınmış olup bu değerdeki yıl boyu görülen sapmalardan ötürü doğabilecek belirsizlikler göz önünde bulundurulmamıștır.

\section{Teşekkür}

$\mathrm{Bu}$ çalıșma, Dokuz Eylül Üniversitesi Rektörlüğü tarafından 2017.KB.FEN.031 numaralı Bilimsel Araştırma Projesi ile desteklenmiştir.

\section{Kaynakça}

[1] Dabiri, J. 2011. Potential Order of Magnitude Enhancement of Wind Farm Power Density via Counter-Rotating Vertical-Axis Wind Turbine Arrays, Journal of Renewable and Sustainable Energy, Cilt. 3. DOI: $10.1063 / 1.3608170$

[2] Karadeniz, Z.H., S. 2015. Düşey Eksenli Rüzgâr Türbini Araștırmalarında Son Gelișmeler, VIII. Yenilenebilir Enerji Kaynakları Sempozyumu, 15-16 Ekim, Adana, 151-155.

[3] Whittlesey, R. W., Liska, S., Dabiri, J. 2010. Fish Schooling as a Basis for Vertical Axis Wind Turbine Farm Design, Bioinspiration \& Biomimetics, Cilt. 5, s. 1-6. DOI: $10.1088 / 1748-3182 / 5 / 3 / 035005$
Kullanılan vektör haritasının çözünürlüğü de hesaplama yaparken büyük önem taşımaktadır. $\mathrm{Bu}$ çalışmada, internet üzerinde bulunabilecek en iyi çözünürlükteki harita olan, 1 ark-saniye $(30 \mathrm{~m})$ çözünürlükteki topografik harita kullanılmıștır.

\section{Sonuç}

Farklı çalışma şekilleri ve etkileşimleri nedeniyle DERT'ler ve eşli çalışan DERT'ler için YEÜ hesaplanmalarında yeni yaklaşımlar geliştirilmesi gerektirmektedir. Bu çalışmada, eşli çalışan tek bir DERT çiftinin YEÜ hesaplamaları için kullanılabilecek bir yöntem önerilmektedir.

Yapılan örnek çalışmada sahaya konumlandırmanın ne kadar önemli olduğu incelenmiş ve doğru konumlandırma ile YEÜ'nin \%11'e kadar artırılabileceği gösterilmiştir. Kullanılan hesaplama yazılımı YERT'ler için geliştirilmiş olduğundan bazı belirsizlikler bulunmaktadır. Bunun sonucunda olușabilecek hataların incelenmesi yöntemi iyileștirecektir.

Eşli çalışan türbin verisinin düz bir sahadan alınmış olması nedeniyle sonuçlarda sapmalar olabilir. Önerilen yöntemin saha koșullarından (pürüzlülük, yüzey șekilleri, engeller) nasıl etkilendiğinin de incelenmesi ve yöntemin saha şartlarına göre düzeltilmesi çalıșılması gereken konulardandır. Ayrıca bu tip türbinlerin sahada kullanımı sırasında oluşacak yeni elektriksel bağlantı şekilleri, lojistik yaklașımları, bakım onarım ihtiyaçları vb. nedeniyle, tüm bu çalışma alanlarının araştırmacılar ve ticari kurumlar için bir firsat olduğu düşünülmektedir.

[4] Kinzel, M., Mulligan, Q., Dabiri, J. 2012. Energy Exchange in an Array of Vertical-Axis Wind Turbines, Journal of Turbulence, Cilt. 13(38), s. 1-13. DOI: 10.1080/14685248.2012.712698

[5] Shamsoddin, S., Fernando, P.A. 2014. Large Eddy Simulation of Vertical Axis Wind Turbine Wakes, Energies, Cilt. $7(2)$, s. 890-912. DOI: $10.3390 /$ en7020890

[6] Tescione, G., Ragni, D., He, C., Simao Ferreira, C.J., van Bussel, G. J. W. 2014. Near Wake Flow Analysis of a Vertical Axis Wind Turbine by Stereoscopic Particle Image Velocimetry, Renewable Energy, Cilt. 70, s. 4761. DOI: $10.1016 /$ j.renene.2014.02.042

[7] Kacprazak, K., Liskiewicz, G., Sobczak, K. 2013. Numerical Investigation of Conventional and Modified Savonius Wind Turbines, Renewable Energy, Cilt. 60, s. 578-585. DOI: 10.1016/j.renene.2013.06.009

[8] Zanforlin, S., Nishino, T. 2016. Fluid Dynamic Mechanisms of Enhanced Power Generation by 
DEU FMD 22(64), 199-208, 2020

Closely Spaced Vertical Axis Wind Turbines, Renewable Energy, An International Journal, Cilt. 99 s. 1213-1226. DOI: 10.1016/j.renene.2016.08.015

[9] Huskey, A., Bowen, A., Jager, D. 2009. Wind Turbine Generator System Power Performance Test Report for the Mariah Windspire 1-kW Wind Turbine, National Renewable Energy Laboratory Technical Report, Proje Numarası: NREL/TP-500-46192

[10] Albadi, M. H., El-Saadany, E. F. 2009. Wind Turbines Capacity Factor Modeling-A Novel Approach: IEEE Transactions On Power Systems, Cilt. 24, s. 1637 1638. DOI: 10.1109/TPWRS.2009.2023274

[11] Mortensen, N. G. 2016. Wind Resource Assessment Using the WAsP Software https://orbit.dtu.dk/ws/files/140943898/Wind re source assessment using the WAsP software DTU Wind Energy E 0135 .pdf (Erișim Tarihi: 23.07.2019). 